\title{
The Problem of Organized Crime in the South American Tri-Border Area: Paraguay, Brazil and Argentina
}

\author{
Stanisław Kosmynka \\ (iD) https://orcid.org/0000-0003-4131-4762 \\ University of Lodz \\ Faculty of International and Political Studies \\ Department of Latin America and Comparative Studies \\ e-mail:skosmynka@uni.lodz.pl
}

\section{Abstract}

The paper shows mechanisms and manifestations of the challenges for the security in the South American Tri-Border Area (Paraguay, Brazil and Argentina). It analyses the background of the activity of chosen organized crime and terrorist groups in this region. The article refers to some social and economic conditions for the spread of violence and illegal business in the area. It is focused on the most important dimensions of these problems and on the strategy implemented by South American governments to fight and prevent organized crime. The paper shows how the security forces deal with the threat and evaluate the impact of these efforts.

Keywords: Tri-Border Area, Argentina, Brazil, Paraguay, security, criminality, terrorism 


\section{Introduction}

Many regions of Latin America have long been struggling with high rates of crime and violence, escalation of which is a result of structural socio-economic and political problems and complex historical conditions of individual countries in this part of the world. The activity of small and organized crime groups has resulted in numerous cases in the crystallization of specific subcultures of violence, which is one of the factors destabilizing the internal situation of some parts of the region, especially in large urban agglomerations. In many countries of Central and South America the instability has allowed criminal organizations to flourish and the contagious spread of violence remains still an unsolved problem (Goubaud 36; García Bravo 12; Medina and Mateu-Gelabert 42-46).

Combining Brazil, Paraguay and Argentina, the border area, known as the Triple Frontera or TBA (Tri-Border Area), is one of the regions that have been struggling with numerous complex problems for years. When one takes into account its location, at the intersection of the three countries, it emerges as a place that generates serious challenges for regional and international security. They result from the activities of criminal groups and mafia structures which found there - especially in the Paraguayan Ciudad del Este - favourable, endogenous conditions - ideal for implementing their extensive interests. The problem of the threat to the security had already existed there, as there was a well-grounded suspicion that some extremist groups, both Latin American ones (like FARC) or those who based their beliefs on the ideologies of Islamic fundamentalism, were operating in the area. This area was in fact considered to be an enclave of violence and small, organized crime, and for a long time perceived as a Latin version of America's Wild West - a dysfunctional area, deprived of any effective state control, functioning "outside the law," and sheltering criminals and terrorists who had found there favourable conditions for their illegal activities.

The aim of the article is to cast some light on the challenges that the security of this region must face, resulting from the activity of criminal groups. The considerations discussed here outline the main areas of activity of some criminal networks operating in the area of the three borders, and efforts undertaken by the authorities of Argentina, Paraguay and Brazil to stop the criminalization of the region. This analysis, thus, includes an evaluation of the mechanisms implemented so far in the fight against small and organized crime in the cross-border area.

The problem of criminal activities in the Tri-Border Area is rarely addressed by Polish scholars. This topic is raised by Spanish and Latin American authors like Geraldine Cuervo Ceballos, Camilo Andrés Devia Garzón, Dina Ortega Avellaneda, Sona Alda Mejías. When it comes to the issue of the efforts to fight crime in Latin America, the publications of Rebeca García Bravo, Juanjo Medina, Pedro MateuGelabert, Emilio Goubaud and Michał Stelmach are especially noteworthy. 


\section{Methodology}

It should be emphasized that the methodology of research on crime and the strategy of its containment imply the necessity to choose an interdisciplinary range of methods. In capturing the main dimensions of criminal activity in the TBA region, integration of the historical method (especially in the context of capturing causeand-effect relations of certain mechanisms) and the systemic one (allowing to see the discussed issues as a set of related elements within which attention focuses both on their component parts, as well as mutual connections) proved to be effective. This also applies to the presence of a terrorist network in this area. In the study of the transformation process of modern terrorism, an important place is occupied by the theory of the network and the work of Marc Sageman, which perceives jihadist cells as a form of social movement composed of numerous informal networks inspiring terrorism (Sageman 29-31). It helps to understand the complex trajectories of radicalization; these, in turn, imply a specific character of preventive measures, which must be reached at the decision-making level by the authorities and at the executive one by appropriate bodies and services.

\section{Criminal activites in the Tri-Border Area}

In 2012, the TBA population was estimated at nearly one million nine hundred thousand people, which indicates a dynamic growth considering the fact that at the beginning of the 1960 s there were only approximately 60,000 people inhabiting the area (Lewis 24). The characteristic features of the three-border zone are its multiculturalism and considerable ethnic diversity. In addition to Brazilians, Argentineans and Paraguayans, there are such nations as the Arabs, Chinese, Koreans, Europeans (e.g. Italians or Germans) and immigrants from other parts of the world who have settled in the TBA. The area is also inhabited by some ethnic minorities, such as: Iranian, Palestinian, Ukrainian or Thai.

Among many various reasons, lack of effective control of the states authorities and corruption of the local authorities have become two major factors that have facilitated criminal activity in the region. At the beginning of the $21^{\text {st }}$ century, many analysts pointed to the apparent dysfunction of the state control in this area. Apart from the local gangs and criminal clans who operated there, there were Colombian, Russian and Chinese mafias, as well as criminal organizations from other parts of the world, including those from Africa (Lynn 4-5) who were running their criminal businesses in the area. Their activities included drug trafficking (mainly cocaine), money laundering, piracy in acquiring and trading of goods (e.g. clothing, music, films, cigarettes, alcohol, electronic equipment, jewellery, toys, sports equipment, etc.) or illegal trade in computer software. According to the calculations 
made on the Brazilian side, in 2012 the illegal trade in the border region amounted to USD 6 billion. The source of these funds was unknown; however, it was evident that to a large extent, they came from criminal practices. Numerous transfers or investments of funds would take place in the banks and various TBA financial institutions. Then, the money travelled to the USA via Uruguay and Brazil. For example, in 2006, as a result of the operation performed by the Brazilian police, a criminal network, dealing in money laundering was trucked just in the area of the three borders. It had been set up and coordinated by a Colombian citizen, Alejandro Pareja García. The businessman invested significant sums of money in gas in Brazil and in petrochemical and fuel industries, including the state sector. These funds came from drug trafficking and went to Brazil via Uruguay. Estimated calculations show that about 17 per cent of the profits of the Colombian drug cartels go to the Brazilian banking system, where they are then "cleaned up" and relocated (Mathieu and Nijo Guarnizo 37-8; Devia Garzón and Ortega Avellaneda 16).

In the 2009 report on the main challenges for the security of the region, attention was drawn to the growing income of criminal organizations stemming from the piracy of DVDs and their illegal sale (Lagos, Dammert 29). The following companies suffered the most losses from smuggling and piracy: Canon, Kodak, Motorola, Nike, Nintendo, Sony, Microsoft and others. It should be added that most of the electronic equipment smuggled into this region came directly from Asia and found its way to TBA thanks to the coordination and cooperation of criminal structures from China, Macau, Taiwan, Korea and Japan with the local (TBA) criminal "representatives." For example, in 2010, the Paraguayan police discovered a transfer route between the Chilean city of Iquique and Ciudad del Este. It is worth noting at the same time that a significant number of Asiatic communities living in the area of the three borders play an important role in distributing illegal goods that often imitate original ones. Police investigations have shown that many of the businesses apparently involved in legitimate commercial activities are, in fact, to a varying degree, connected with the criminal structures. Undoubtedly, these hidden relationships have significantly hampered the effectiveness of the work of law enforcement agents. The extent to which the aforementioned are concerned for the piracy of their goods and the ensuing significant losses, is evidenced by the fact that Canon, Kodak, Motorola and Nintendo have begun private investigations in recent years in order to diagnose the scale of these illegal practices and undertake appropriate steps to remedy the situation (Lewis 68).

The unlawful activities of criminal groups in the three-border area also included much more severe crimes, such as human trafficking. A lot of women (often under-aged) who were abducted and forced into prostitution were left in these areas. In the first decade of the $21^{\text {st }}$ century, a worrying increase in sexual violence against minors was recorded in the Paraguayan area of Ciudad del Este. It is commonly known that profits from prostitution constitute one of the most important sources 
of income of criminal organizations; hence it is not surprising that a significant part of it is controlled by mafia structures operating in the triangle zone. In June 2000, the Brazilian daily paper $O$ Globo already informed about the growing involvement of organized criminal groups from Russia in recruiting (and often abducting) in these areas women who were then sent to brothels in Europe and Israel (Solís and Rojas Aravena 132-33). Of course, such undertakings would not have been possible without aid from local criminal structures operating in the region. Human trafficking, meaning in this context quasi-sexual slavery, is one of the major problems affecting this area. The same mechanism is always applied in order to recruit people to work in the prostitution sector. It should be emphasized, however, that the recruited are often unaware of the real nature of the employment offered to them. It is very difficult to assess how many young girls and boys (also under the age of 16) coming from small towns of Brazil, Paraguay, Argentina have been tempted by the prospect of lucrative work, and then sent to brothels, and forced to work as prostitutes. It is worth adding that the area of the three borders has become an important centre of sex tourism not only for the Hispanics, but also for the incomers from Europe, the United States and Canada, often benefiting from child prostitution as well.

In this context, it is significant that the TBA is made up of areas that are difficult to access and poorly monitored; a common phenomenon here is the aforementioned corruption of law enforcement agents. A number of analyses show that especially the part belonging to Paraguay (with its centre, Ciudad del Este, which has one of the highest fatalities rates in the region per year) has been the place of frequent violation of law and violence practices for years. In 2010s, this city became a kind of "crime tax-free zone", where many people go to in order to buy goods at a much lower price. The goods are sold cheaply as they come from smuggling and robberies (eg. stolen cars). Unfortunately, the piracy process is also facilitated by the weakness of the Paraguayan legislation system, which enables patenting of international brands that are not located in the country (Frühling Ehrlich 42). A lot of methods and routes are used to smuggle goods from Ciudad del Este to Argentina and Brazil. Transport by water seems to play a vital role here, especially via the River Paraná and Brazilian artificial reservoir, which was formed by the side of the Itaipú dam. However, monitoring these trajectories over the years has been highly ineffective. Between 30 to 40 thousand people travel daily by the so-called "Friendship Bridge," connecting Ciudad del Este and Foz de Iguaçu, which greatly facilitates the circulation of goods, including those carried illegally. Therefore, in March 2015, the Brazilian authorities announced the establishment of an Integrated Control Centre to develop mechanisms to control the flow of goods more effectively and to reduce the scale of smuggling.

Among the wide range of criminal activities, falsification should be mentioned as well. By falsification of identity documents, including passports, visas, driving 
licenses, etc. lawbreakers offer considerable help for people who are in conflict with the law and are looking for permanent or temporary shelter in the discussed area. An investigation conducted in Argentina and Brazil, as well as other countries, led to the disclosure of fake documents of yet another type (birth certificates) and often pointed to the three-border region, in which these documents were prepared and then used to change a person's identity or facilitate their illegal border crossing (Rocha and Zorovich 332).

The zone has also become an important area on the map of the Latin American drug industry, which is known as a transnational phenomenon and contributes to the escalation of violence in many Latin American countries, constituting a severe unresolved challenge on both a local and an international scale (ŚniadeckaKotarska 32-44). The criminalization of the TBA is generated by narco-handling to a significant extent (Bergman 57-62). The activity of Colombian cartels plays an important role here. For example, in 2006, as a result of anti-trafficking operations in Colombia, mafia organizations were forced to relocate some of their interests into regions that were safer for them, where the threat of prosecution from law enforcement authorities was much smaller. According to the reports of the Argentinean special services, the area of the city of Misiones, south of Puerto Iguazú, became a new base of drug smuggling, with the substances coming from Paraguay, among other places (Boote 156; Cuervo Ceballos 23). On the territory of TBA, there was a repeated turnover of weapons and drugs; the profit from the latter was used to purchase the former. The transactions were also attended by representatives of the Colombian guerrilla FARC who were operating in Paraguay and Brazil, especially in the area of the Iguaçu Falls, thus coming from a geographically quite distant region.

In the smuggling of psychoactive substances, there were other 'actors' who were active on the crime scene. In May 2008, the Brazilian police managed to capture over 4.5 tons of marijuana hidden in a wagon under rice packs. The organization called Friends of Friends (Amigos de Amigos) was behind it and orchestrated the whole attempt to smuggle the drug. The cargo also included weapons and ammunition transported from Paraguay to Brazil via Foz de Iguaçu. John Boote stresses that the attempt to transport such a large amount of drugs encourages reflection on the ineffectiveness of law enforcement agencies in these three countries and the lack of effective monitoring (Boote 157). This observation seems all the more justified if other cases of drug and weapon trafficking in the TBA are also taken into account. In this context, the hypothesis about the connections of drug gangs operating in the favela of Sao Paulo and Rio de Janeiro with criminal groups active in the border area is worth considering (Hudson 28).

A classic example of the mechanisms of illegal transport and transit of drugs and other illegal substances may be the practice of using a specific "corridor" leading through Ciudad del Este and Foz de Iguaçu to Brazilian ports such as Parangua, 
Santos, Rio de Janeiro, and from there to the United States and destinations even more distant - Africa and Europe. Despite the efforts of the Latin American authorities to fight smuggling of psychoactive substances, in many cases they have not been sufficiently effective. The report of the Brazilian anti-drug service from 2007 showed that only in the three months of that year (January-March) in the city of Foz de Iguaçu, police managed to seize about $475 \mathrm{~kg}$ of marijuana, $187 \mathrm{~kg}$ of cocaine and over $4 \mathrm{~kg}$ of the so-called "crack". That indicated an increase of $27 \%$ compared to 2006 (Alvárez and Manzotti 39). Marijuana goes to the border zone, mainly from the territory of Paraguay. It is worth stressing that apart from the sea and land, trafficking by air plays an important role in transporting drugs. Thus, to facilitate the process of trafficking by air, in the less inhabited parts of Paraguay and Argentina, such as the province of Misiones, makeshift airports were built. According to the statistical data from 2010, their number only in Argentina was estimated at around 100 (Alvárez and Manzotti 40). What is more, airplanes have often been targeted. They are still being highjacked, then repainted and hidden away by the criminal groups who remain active, also in the TBA region.

In addition to drugs, such as marijuana and cocaine, there are also numerous examples of the practice of smuggling other substances, e.g. some pharmacological agents (Viagra) or cigarettes. The latter, often being fakes of well-known brands, like Malboro, and functioning under such names as Eight, Te, Rodeo, Calvert, etc., have been produced mainly in Paraguay for years, from where they reach other countries. This generates substantial profits for those trading in it, and huge losses for the state budget, due to tax evasion or avoiding to pay other applicable fees. For example, in 2012, the average price of a packet of cigarettes sold on the markets of the cross-border area fluctuated around 1.5 US dollars. It is estimated that this region produces as much as 68 billion cigarettes a year, $90 \%$ of which goes to the black market and at the same time represents about $20 \%$ of the global share of these stimulants (Umaña 34). The implementation of this procedure uses, among other methods, the so-called 'mobile factory model', meaning there is no stationary plant and production is located on lorry trailers. Naturally, this greatly hinders the fight against illegal production. The report from 2012 showed the routes of illegal transport of cigarettes from Ciudad del Este down to:

a) Brazil, to the Guaíra area, which is one of the main centres of trafficking of psychoactive substances (river transport). From there, they then go to Sao Paulo, Rio de Janeiro and other major Brazilian cities;

b) the eastern coast of the United States and the Indian reserves located in the southwest of the USA;

c) the Caribbean and Central America, especially to Aruba and Panama;

d) Ireland and other Western European countries (by sea and air) (Umaña 34).

The above data illustrates how important the Three-Zone region is in the trade of tobacco substances, also in the context of international, if not global, 
co-participation of criminal structures, who always derive profits from production and trade in various types of stimulants.

In connection with the trajectories of drug trafficking, it is also important to mention the activity of a Russian mafia (from the Caucasus region) in Argentina. The country became an important transit link for them in the transportation of drugs from the Andean region to Europe and Africa. In the zone of the Three Borders, such Russian criminal groups as Podolskaya, Mzukinskaya, Tambovskaya, and Solncevskaya have successfully operated, focusing their activity on drug trafficking, arms dealing and smuggling of goods. Smuggling is usually carried out using container ships on board of which there are large quantities of commercial cargo, which are then sent to various European ports. Those international criminal structures (including the Chechen mafia) have also been involved in illegal transport of weapons (Bagley 132). The Chechen mob has links with Islamic radicals. Arms trade has been a characteristic element of the activity of such mafias and terrorist organizations as the Colombian FARC or the Lebanese group Hezbollah - both in the region of TBA. It is worth recalling that the members of FARC were involved in the murder of Cecilia Cubas, the daughter of Vice-President of Paraguay, Raul Cubas, in 2005. Her abduction and murder was carried out by an extremist party called Free Fatherland (Partido de Patria Libre), who had been inspired by the FARC ideology and who maintained strong contacts with this organization (Alvárez and Manzotti 112). Weapons are smuggled especially from the areas of Brazil and Argentina - those Latin American countries where the production of military equipment is quite high - to Paraguay. Illegal weapons that have been sold included AK-47 rifles and machine guns (e.g. AR-15 or Colt M-4 rifles), as well as their home-made equivalents. In the street bazaars, purchase of such equipment is not only easier, but it is also available at much lower prices (Umaña 36). It is not necessarily only the local gangs who benefit from arms trading as various international criminal and terrorist organizations find it an important source of obtaining this type of equipment. This procedure not only allowed them to operate but also generated lucrative profits.

At the turn of the century, the Three-Border Zone became a convenient place for the aforementioned "money laundering" as well, which usually constitutes an integral element of criminal activities. For a number of years, the cities of Foz de Iguaçu and Ciudad del Este have been important centres of transferring and relocating considerable amounts of money of an unknown origin. Interestingly, this did not concern Argentinean Puerto Iguazú. It was caused by the unstable financial situation of Argentina at the beginning of the new millennium, which, in turn, constituted a disincentive factor for criminal organizations to deposit funds there. In the mid and late 1990s, and at the beginning of the new millennium, it was Paraguay that grew in importance and became a place of international operations involving illegally obtained funds. This role was so important that Ciudad 
del Este was compared to being the "very heart of the underground economy of the country," in which people belonging to the power elites or holding high executive positions frequently played significant parts. For example, in July 2000, it was revealed that the general of the Paraguay Army, Lino Oviedo, had carried out illegal financial operations in Foz de Iguaçu and Ciudad del Este reaching the total value of about $\$ 10$ million. At the turn of the century, it was estimated that every year in the TBA, money laundering activities generated the sums of about USD 12 billion, which had a destabilizing effect on the regional financial system (Umaña 34). Thus, it is now Paraguay that is considered one of the main scenes of this crime (Devia Garzón and Ortega Avellaneda 17).

\section{The convergence of organized crime and terrorism}

The area of the Three Borders was also associated with the activity of terrorist organizations, including those of provenance that was very distant geographically. In 1994, Israeli special services signalled that the TBA was used by the cells of the previously mentioned Hezbollah group for logistic and operational activities. In subsequent years, this information was confirmed by the US Department of State; then reported by the Argentinean and Brazilian press as well. It was established that some of the suicide bombers - those responsible for the deadly attacks in Buenos Aires - had come from there. On March 17, 1992, the attack on the Israeli embassy was carried out in the Argentinian capital causing 29 deaths and leaving 242 people injured. Two years later, on July 17, 1994, the aim of the next attack in Buenos Aires was a cultural centre - the Argentinian-Israeli Association (Asociación Mutual Israelí-Argentina - AMIA). At that time, nearly 90 people died, and more than a hundred were injured. These acts of terror were intertwined with the ideology behind them and the strategy of this organization, whose very existence was determined by the Israeli-Palestinian conflict. This strategy, by the way, was also manifested in the preparation and implementation of terrorist projects outside the Middle East region - in European countries (e.g. Spain in the 1980s), as well as in other parts of the world.

The opinion that it was an "outlaw" area (especially the border areas of Paraguay) significantly facilitated activities of terrorist cells. In 2001 and 2003, the American CIA indicated that the area was crucial in the development of radical Islamism in Latin America. It is worth recalling that on May 6, 2002, the US vice president, Dick Cheney, stressed that one of the American priorities was to monitor the border zone of Paraguay, Brazil and Argentina to neutralize terrorist operations carried out there, while six months later, the head of the FBI, Robert Mueller, talked about Al-Qaeda cells operating in this area (Gunaratna 246-247; Chossudovsky 84; Kosmynka 143-49). Also, the American and Israeli intelligence agencies indicated 
that certain cells of Islamist terrorist organizations, such as Hezbollah, Hamas, Jamaat al-Islamiyya, Jihad and Al-Qaeda were taking up their activity in the area of the Three Borders. (Lynn 24; Dumitrascu 6-7). Although much of this information has not been confirmed and remained only in the sphere of hypotheses (this area being associated primarily with activities of criminal groups and high rates of violence), the presence of Islamic radicals (Shiite), especially associated with Hezbollah or their supporters, seems to be indisputable. Some specialists cite much information, which shows that TBA has become - especially at the turn of the century - a zone of Hezbollah's special activity, whose representatives on numerous occasions cooperated with al-Qaeda structures, as well (Hudson 29). A number of analyses indicate the presence of many active and "dormant" cells of this group at the beginning of the 21st century, with the number of their members being estimated at approximately 460 people (Noriega and Cárdenas 29; See Costanza 47; Ortiz 186; Pozo Guindo 146-97; Hudson 94).

It was already in the 1990 os that the Paraguay police repeatedly intercepted propaganda materials of the Hezbollah group, and also got a lead on channels of financial operations from which the resources - flowing from the United States - went to the zone of Three Borders, and then to Iran and Lebanon (Gunaratna 247). Located in Ciudad del Este, one of the mosques had numerously been used to propagate the idea of religious and political radicalism. In the "Tri-Border region" a series of illegal interests were being dealt with, both locally and internationally, while violence spread (homicide statistics make it one of the most dangerous in the world). It was not uncommon for public officials to be involved in illegal activities, including those with the criminal underworld. Terrorists were often engaged in these activities, which is not surprising considering the well-known fact that there are strong links between terrorism and organized crime in obtaining funds from drug, arms or people trafficking as well as from pandering, financial embezzlement and money laundering. Only in the years 1999-2001, about 50 to 500 million dollars were sent by the Arab communities, mostly living in the Brazilian part of the zone, to various Paraguayan financial institutions belonging to Hezbollah and to Hamas (Connell 184-85). Therefore, it is not insignificant to notice that there is an evident convergence between international networks of organized crime and terrorism, whose functioning is to a large extent conditioned by obtaining notable financial support, which, in turn, leads to participation in drug, arms and people trafficking, in smuggling of goods, illegal financial operations, etc. All of these carried out in the TBA area are a perfect exemplification of such a convergence, as evidenced by the examples to follow.

A significant number of revealed cases shows how much money Hezbollah gained from illegal ventures carried out in the Three-Frontier zone (for instance, from gunrunning and drug trafficking). For example, when in February 2000, a Lebanese businessman, Chalil Mehari, was arrested in Ciudad del Este, an analysis of the contents of the hard disk of his computer revealed numerous 
propaganda materials belonging to this organization as well as traces of transfer of about 7,00o dollars to the accounts of its branches in Chile, the USA, Canada and Lebanon. In May 2002, another citizen of Lebanese origin, Ali Assi, carrying ten kilos of cocaine in his baggage, was detained at the airport in Beirut. He was a "businessman" cooperating with his brother-in-law, Ali Hasan Abadia, in Ciudad del Este. Abadia was, in turn, considered to be the coordinator of Hezbullah's financial undertakings in the region. A year later, subsequent arrests finally confirmed the organization's involvement in the narco trade.

One of the detained people was another businessman from the cross-border area who was proven to traffic drugs and have ties with Assad Ahmad Barakat, i.e. one of the planners of the attack on AMIA in Argentina, leading extensive interests, among other places, in Chile and Brazil (Ortiz 145-146). It is worth adding that the brother of the latter, Muhammad Barakat, also actively participated in activities for Hezbollah. On his computer, the Paraguayan police found many propaganda materials belonging to the organization, including those affirming suicide bombings, the procedure so significant for jihadism. He was also proven contact with the leader of the party, Hassan Nasrallah. The Chilean of Lebanese origin was accused along with two comrades of handling the financial activities for the organization. He came to Latin America from Lebanon in 1985 and developed a network of extensive interests in Paraguay, in Ciudad del Este. In 2001, after a short stay in Brazil, he came to Chile and settled in Iquique. In June 2002, his brother Assad was arrested, which led to the suspension of their business. According to some sources, the Barakat brothers were doing business with Usama ibn Laden and thanks to the funds they had collected, Al-Qaeda's cell in Beirut was established (Hudson 22).

It should also be added that the Chilean city of Iquique became one of the centres in which Islamist-related Muslims, such as the Barakat brothers, were pursuing legal and illegal businesses; some of the profits coming from these ventures fed the organization. Isaac Caro emphasizes how important the strategic location of Iquique was, allowing for convenient air connections with the Three-Border zone and centres in Peru and Bolivia. At the same time, it should be emphasized that the majority of the Muslim community living there, centred around the mosque of Bilal de Iquique (Caro 23), distanced themselves from radicalism. The Barakat brothers created a very dynamic criminal and terrorist network, operating not only in the Three Borders, but also in other parts of the world. This structure drew financial profits, from, among others, money laundering, piracy of goods (e.g. DVDs), extortion, racketeering, blackmail. At the same time, as mentioned above, some of the profits contributed to the Hezbollah budget. According to estimates from 2009, the financial turnover of the Barakat network in The Border zone reached a value of approx. USD 20 million annually, of which about 3.5 million were sent to the accounts of the Lebanese group (Caro 23). 
Profits from links with organized crime mainly concerned indirect mechanisms of financing terrorism. In addition to tangible financial benefits, logistic aspects necessary to conduct such activities played a significant role. They concerned, for example, obtaining weapons, equipment and other materials, collecting them and transporting them. A good illustration of this type of relations is the cooperation of the Egyptian group Jamaat al-Islamija or Hezbollah with Chinese gangs from the area of the Three Borders.

In 2000, in a Cypriot port, a large shipment of weapons addressed to this organization was found on a transport ship sailing under the flag of Cameroon. The transport had come from the zone of Three Borders and had been sent by a Chinese criminal group, Sung-I. Another clan from this region, known as the "Ming Family", mediated in the transfer of funds from the Jamat al-Islamiyya, also from the Triangle Zone, to the area of the so called "financial paradise" - to Guiana and the Cayman Islands (Caro 34). In 2003, as a result of an extensive international operation of services to combat organized crime (American, Colombian and Spanish units), operating under the code name "Titan", one of the largest drug nets originating in Colombia was broken up. Over one hundred people who had been involved in drug trafficking were arrested. Some of them had connections with the Hezbollah organization, such as Lebanon Chocri Mahmud Harb, who was a link in cooperation between this group and the Cartel of Medellin. The activities of these and other criminal structures had an international scope; they were being signed by a network of various facade companies and associations involved in money laundering and located in Panama, Costa Rica, China and the countries of the Middle East.

In July 2010, a large transport of weapons was intercepted in the Paraguayan part of the TBA, which was supposed to reach Lebanon and Syria by sea. In the CrossBorder zone, Interpol agents arrested Mussa Hamadan, Hezbollah's representative coordinating this venture. Among other accusations, he was found to have participated in smuggling of weapons on the territory of the United States and Syria. The investigation determined that Hamdan had been involved in a planned operation of delivering a load of 1,200 Colt M-4 machine guns to the Middle East. According to some estimated calculations, Hezbollah's profits obtained from smuggling reach hundreds of millions of dollars annually (Connell 189). Although the US Department of State's 2012 report on the contemporary shape of terrorist threats does not list any jihadist extremism activities in this region, this does not undermine the fact that the organizations have numerous followers among the immigrant communities who live in this part of Latin America, who support the program of armed religious-political radicalism and feel an ideological closeness with them, supporting them materially and morally. The total sum of financial support is, of course, unknown; however, calculations based on reports of police and anti-terrorist services report USD 20 to 500 million annually going to Hezbollah and Hamas 
from people and institutions residing in the TBA region (Connell 190). In addition to the funds obtained from the abovementioned illegal commercial transactions and business activities, one should also remember about donations of various types, undertakings bearing the hallmarks of charity and charity campaigns or transferring funds within the Islam world and Islamic immigrant communities using hawala - the informal banking system, finally, practising one of the pillars of this religion - zakat, meaning the alms command. All this makes it extremely difficult to control and monitor the sources and directions of the circulation of financial sums.

The activity scope of terrorist groups supporters in this region is confirmed by a number of other police operations, as a result of which people mainly from Lebanon and Iran were arrested and accused of belonging to Hezbollah. In the autumn of 1998, in Ciudad del Este, Ayman Hachel and Mohamed Astaraki were arrested. Both had been gathering information about the Israeli embassy in Asunción, which allowed the police to presume that a coup was being planned for it. At the beginning of 2000, Alil Khalil Merhi was arrested while raising funds for the grouping. Other Islamists arrested in the Triangle Area were accused of cooperation with other terrorist organizations, including Al-Qaeda.

In November 1996, Marwan as-Sadafi was arrested on charges of participation in the preparation of the coup of February 26, 1993, in New York for the World Trade Center building. In the autumn of 200o, Salah Abdul Karim Yassin, a Hamas fighter who had cooperated with the Egyptian group Jihad, was arrested on the grounds of using fake documents. He was accused of planning an attack on the US and Israel embassies in Paraguay. He was sentenced to four years in prison (Gleis and Berti 71-5).

We should remember that the activity of Hezbollah representatives in Latin America was also influenced by the friendly relations with Venezuela, especially during the presidency of Hugo Chávez and Nicolas Maduro, with Iran, manifesting themselves in a series of mutual visits of the heads of both states. They resulted in implantation of Hezbollah cells in Venezuela, including on the island of Margarita (Gleis and Berti 157; Kosmynka, "Conditions and Relations Schemes" 303-17). As mentioned above, the activity of the Islamist extremism network in the TBA region has caused concern not only to the authorities of the countries of the ThreeZone Region but also to the US intelligence agencies. As a result, the FBI undertook a number of operations in this area, aimed at working out the cells operating there and neutralizing their logistic and operational activities. These efforts were accompanied by the fight against international criminal structures, whose interests were often interwoven with the undertakings of terrorist groups. Also, the authorities of the countries of the Three Borders undertook and carried out numerous police operations aimed at improving the security in the region. For example, in 2005, the operation under the code name "Jupiter" was launched, which was aimed 
at sealing the borders and reducing the scale of smuggling. Interpol got involved in it, as well. As a result, about seven hundred people were detained and goods worth over USD 300 million were seized (Caro 34). Although it was impressive, it did not mean the practice had been stopped or the criminal structures involved had been eliminated. The mentioned effects of this operation only gave an idea of the scale of this phenomenon.

\section{The efforts to combat organized crime}

It is worth noting that as part of the war on terror, especially after September, the 11th, the United States undertook a number of initiatives aimed at cooperating with the countries of the region to have control over the area of the three borders and prevent the development of jihadist extremism. To implement this, the socalled $3+1$ Group (Argentina, Brazil, Paraguay and the United States) was set up, which focused its efforts on jointly increasing the security of the zone and combating organized crime and terrorism. Its assumptions included information exchange, coordination of activities, joint patrols in the area of Itaipuú lake, etc. After the terrorist attacks on the United States, when the international counter-terrorism strategy got intensified and resulted in close surveillance and monitoring of the CrossBorder zone', Islamist activities in South America became more difficult to carry out and less frequent when compared to the time from before September, the $11^{\text {th }}$. Many activists were arrested, a large number of them left the region and went to other places in Latin America where various communities from the Arab countries continued their activities. In the years 2001-2004, around eleven thousand people left the zone (Caro 40). Some of them returned to the Middle East, some went to other Latin American countries (e.g. Venezuela), some to Europe.

Argentina is involved in the fight against organized crime. These include legal regulations facilitating the prosecution of financing terrorist activities, as well as measures to ensure transparency of trade and circulation of goods. In 2009, the authorities of this country adopted an amendment to the act penalizing all forms of human trafficking, which was aimed particularly at fighting the sphere of sexual services (including prostitution). Thanks to it, numerous hustlers and other people involved in kidnapping and selling women and juveniles were arrested. Additionally, a number of victims were freed. Despite these efforts, however, averting of the problem was only partial, which resulted, among other reasons, from the ineffectiveness of the judicial system and lack of proper care or protection of victims, who were often terrorized in order to prevent them from giving testimony. In turn, a bigger success can be attributed to the activities of the Argentinian intelligence, whose information allowed to uncover part of criminal and extremist structures (e.g. information provided by the Argentinian intelligence to the Paraguayan party 
which enabled to break up the Barakat's network). Cooperation with the US intelligence and the countries of the region is very important in this field. During the administration of Cristina Fernández de Kirchner (2007-2015), land and air operations were conducted, dictated by the need to improve monitoring of the border areas, which were the scene of particular activities of criminal groups. In cooperation with the Brazilian side, there were also introduced measures to integrate intelligence work aimed at dissolving criminal networks which profited from human trafficking. President Mauricio Macri's strategy, in turn, included institutional reforms or appointment of additional divisions and bodies to deal with the fight against organized crime. Equipping law enforcement agencies and the army with additional prerogatives in this struggle (e.g. the right to shoot down aircraft or missiles that are suspected of drug trafficking) made the reforms introduced by Macri sometimes referred to as "militarization of the security sector" (Devia Garzón and Ortega Avellaneda 20; Mejías 4).

The authorities of Brazil have also intensified efforts to fight crime in recent years, which has been reflected in a number of initiatives implemented, including the ones within the Brazilian part of the Cross-border zone. These undertakings included, for example, regulations for greater transparency of banking sector operations, and this was dictated by the intention of blocking the mechanisms of money laundering. Actions of the Brazilian side also include new legislative initiatives dictated by the need to reduce losses to the budget caused by smuggling (the so-called Sacoleiro Act of 2009), as well as steps taken to improve the security of the region. As for the latter aspect, the "Agata 2" operation, which started in 2009, is worth mentioning as an example. It was not only a police but also a military operation - about one thousand soldiers took part in it - which demonstrates the size of the challenges and the necessity of engaging big-scale countermeasures. It covered the south-western border zone of Brazil. It is estimated that thanks to the military patrols and increased zone monitoring, the illegal flow of persons and vehicles from Ciudad del Este to Foz de Iguaçu has decreased as much as approx. 50\% (Umaña 4). It is worth noting that the control of this area has become more effective recently thanks to the use of the latest technology, as well, such as the unmanned aircraft drone, constructed in Israel, which patrols the border region. During the administration of Lula da Silva (2003-2011) and Dilma Rouseff (2011-2016), steps were taken to modernize the armed forces and use them more efficiently in the fight against organized crime, especially in the border areas, and in controlling access to firearms. On balance, however, the overall effect of these measures cannot be considered satisfactory.

Paraguay, as mentioned above, enjoys the infamous reputation of the least-efficient country as far as the fight against petty and organized crime is concerned, with the part of the TBA that belongs to this country being rightly considered exceptionally criminogenic. This situation is the result of previously stressed structural 
conditions: high level of corruption of civil servants, and often also representatives of law enforcement, maladjustment of legal regulations and ineffectiveness of their enforcement, deficiency of effective banking sector regulation, lack of adequate control over Paraguayan part of TBA, etc. The scale of challenges gains additional dimensions if we consider mechanisms convenient for the activity of terrorist cells in this area. One of the recent examples of evidence of the implementation of extremist projects was the detention in June 2010 in Ciudad del Este one of Hezbollah representative, Mussy Hamdan, who, on behalf of the organization, coordinated part of its foreign financial operations. The Paraguayan authorities have declared on several occasions to intensify their efforts to combat the security of the zone and to take appropriate measures also in cooperation with other countries in the region. An example of such initiatives was the "Southern Frontier" operation implemented in cooperation with Brazil in 2008, in which over 1,300 soldiers took part, alongside a number of planes and helicopters to monitor the zone and fight against smuggling of goods. However, the effectiveness of this type of action is not sufficient, it only leads to a temporary weakening of criminal structures and a breakdown of some of them; their place is quite quickly taken up by new ones. Also in the case of Paraguay, there is clearly a tendency to militarize security policy; during the reigns of Fernando Lugo (2008-2013) and Horacio Cartes (2013-2018), military operations in the Border regions were targeted at criminal networks. In 2015, a special investigative division was established with the aim of initiating initiatives against the procedure of money laundering. Better coordination between the police and judicial instruments with the Brazilian side was to be introduced.

It is the very cooperation of the countries of the region at the political and operational level that is an important factor affecting the effectiveness of the fight against organized crime. In recent years, a number of joint, coordinated projects have been implemented. An example of this is the INTERPOL operation carried out in April 2016, in which about 300 Brazilian, Paraguayan and Argentine police officers took part. As a result, 25 people were detained, $750 \mathrm{~kg}$ of psychoactive substances were seized (mainly marijuana and cocaine), and a dozen or so stolen cars were recovered (Organized Crime Network). The need to improve the joint strategy for combating organized crime has been the subject of talks between the Presidents of Paraguay, Brazil and Argentina (Mario Abdo Benitez, Michel Temer and Mauricio Macri) in June 2018.

\section{Conclusion}

Summing up, the conditions outlined above mean that for many years the Border zone has been an area affected by a special type of challenges and threats resulting from complex links of petty and organized crime, often interweaving its 
interests with terrorist structures. Similar mechanisms that complex endogenous catalysts project into, are illustrated by some examples of other regions in different parts of the world, including the African continent, which are characterized by dysfunctionality in terms of effective state control. The phenomenon mentioned above revels also the challenges for the internetional security that may result form the symbiotic relationship between tha transnational organized crime and terrorism. The exemplification of these mechanisms may be the situation on the LibyanChadian, Chadian-Nigerian borders, or in the neighbouring Mali and Burkina Faso area of the Tillabéri border zone - where the activity of jihadist groups declare loyalty to the so-called Islamic State. In all of these cases, the lack of harmonization of legal instruments, insufficient efficiency of state bodies, services and operational divisions, structural deficiencies, political and socio-economic problems, corruption and other factors affect the security of these regions and make them the areas of intense criminal activity and sometimes also subversive organizations.

It is worth noting that the challenges generated by the activity of criminal structures have long been characterized by the supra-regional and international dimension. Despite the multifaceted initiatives undertaken by the authorities of Brazil, Argentina and Paraguay to improve security in the zone, the activities of organizations and criminal groups in the TBA area still pose a challenge for the authorities and reduce the security of citizens. In this context, along with the increase in global terrorist threats, i.e. after the coup of September 11, 2001, the region became the area of particular interest to the intelligence services of many countries. Undoubtedly, the implementation of various criminal activities had previously been possible due to emphasized here long-term inefficiency of local and central authorities of the three countries in the fight against crime.

Although many projects and initiatives have been implemented and more are still being planned, the effectiveness remains insufficient in many fields, which is commented on by many experts. One of them, Geraldine Cuervo Ceballos, emphasizes the importance of transnational mechanisms in the functioning of organized crime (Cuervo Ceballos 24). The main findings of this analysis stress that monitoring and preventive actions introduced in the Tri-Border Area should include further, in-depth implementation of coordinated efforts focusing on combating crime, as well as introducing more effective mechanisms in the fight against corruption, improving banking sector control and border sealing. In this respect, integration of the actions of the authorities and law enforcement agencies of Argentina, Brazil and Paraguay should be particularly important, as well as joint efforts to promote transparency of the public sphere, which would hinder corruption of local politicians and officers. It should be remembered that the successful implementation of these projects is also influenced by the effectiveness of wider cooperation on the international arena, including the United States. 


\section{Works Cited}

Anuario 2012 de la seguridad regional en América Latina y el Caribe. Eds. H. Mathieu, C. Nińo Guarnizo, Bogotá 2012.

Alvárez, A. E., Manzotti, G. C., "El estado de la seguridad en América Latina.” Estado, democracia y seguridad ciudadana. Aportes para el debate. Eds. A. Alvárez, Buenos Aires: Programa Naciones Unidas para el Desarrollo, 2008.

Bagley, B. M. “Globalización y crimen organizado en Latinoamérica y el Caribe.” Crimen organizado en América Latina y el Caribe. Eds. L. Guillermo Solís, F. Rojas Aravena, Santiago de Chile: FLACSO, 2008.

Bergman, M. Illegal Drugs, Drug Trafficking and Violence in Latin America. Buenos Aires: Springer, 2018.

Boote, J. A Criminal Heaven: the Tri-Border Area of South America. Federal Research Division, December 2010.

Caro, I. "Presencia de movimientos chiítas en América Latina." Latin American Research Review 46.1 (2011): 177-193.

Chossudovsky, M. America's War on Terrorism, Quebec: Global Research, 2005.

Connell, C. C. Understanding Islam and Its Impact on Latin America, Alabama 2004.

Costanza, W. "Hizballah and Its Mission in Latin America." Studies in Conflict \& Terrorism 35.3 (2012): 193-210.

Crimen organizado en América Latina y el Caribe. Eds. L. G. Solís, F. Rojas Aravena, Santiago de Chile: FLACSO, 2008.

Cuervo Ceballos, G. "El crimen organizado transnacional como una amenaza híbrida para la Triple Fronetra (Argentina, Paraguay y Brasil).” Revista Científica 16.23 (2018): 43-61.

Devia Garzón, C. A., Ortega Avellaneda, D. A. “Características y desafíos del crimen organizado transnacional en la Triple Frontera: Argentina-Paraguay-Brasil.” Revista Criminalidad 61.1 (2019): 9-28.

Dumitrascu, A. El radicalismo islámico en América Latina. De Hezbolá al Daesh, Instituto Espanol de Estudios Estratégicos, "Documento Opinión”, 9 de diciembre de 2016.

Estado, democracia y seguridad ciudadana. Aportes para el debate. Eds. A. Alvárez, Buenos Aires: Programa Naciones Unidas para el Desarrollo, 2008.

Frühling Ehrlich, H. "Una mirada realista a los programas de policía comunitaria en América Latina." Seguridad Ciudadana en América Latina. Miradas críticas a procesos institucionales. Eds. H. Frühling Ehrlich, Santiago de Chile: Romina Nespolo, 2011.

García Bravo, R. Maras en Centroamérica y en México (Costa Rica, Guatemala, Handuras, Nicaragua, Panamá, El Salvador). Comisión Española de Ayuda al Refugiado, Madrid, 2013. 
Gleis, J. L., Berti, B. Hezbollah and Hamas. A Comparative Study, Baltimore: Johns Hopkins University Press, 2012.

Goubaud, E. "Maras y pandillas en Centroamérica." URVIO. Revista Latinoamericana de Estudios de Seguridad 4 (2008): 35-46.

Guanaratna, R. Al Qaeda. Viaje al interior del terrorismo islamista, Barcelona: Servidoc, 2003.

Hudson, R. Terrorist and Organized Crime Groups in the Tri-Border Area (TBA) of South America, Washington: A Report Prepared by the Federal Research Division, 2003.

Kosmynka, S. "Echa terroryzmu islamistycznego w Ameryce Łacińskiej." Transformacje demokratyczne $w$ Ameryce Łacińskiej. Problemy - wyzwania - implikacje. Eds. K. Krzywicka, Lublin: Wydawnictwo Uniwersytetu Marii Curie-Skłodowskiej, 2014.

Kosmynka S. "Uwarunkowania i płaszczyzny stosunków wenezuelsko-irańskich w okresie rządów prezydentów Hugo Chaveza i Nicolasa Maduro.” Badanie polityki zagranicznej państwa. Stany Zjednoczone, Azja Wschodnia, Bliski Wschód \& Ameryka Łacińska. Eds. P. Matera, M. Pietrasiak, R. Bania, M. Stelmach, Warszawa: Rambler, 2017.

Lagos, M., Dammert, L. "La Seguridad Ciudadana. El problema principal de América Latina.” Corporación Latinobarómetro, Lima (2012): 1-61.

Lewis, D. K. A South American Frontier: The Tri-border Region, New York: Chelsea House Publication, 2006.

Lynn, J. La amenaza terrorista en la Triple Frontera: los problemas de seguridad en La frontera de Argentina, Brasil y Paraguay, Madrid: Editorial Academia Española, 2011.

Medina, J., Mateu-Gelabert, P. Maras y pandillas, comunidad y policía en Centroamérica. Hallazgos de un estudio integral, DEMOSCOPÍA S.A., 2007.

Mejías, S. A. Los nuevos roles de las fuerzas armadas uruguayas y argentinas: la contribución a la lucha contra el narcotráfico, siguiendo la tendencia regional, Real Instituto Elcano, Estudios Internacionales y Estratégicos, „ARI”, 31 de julio de 2018.

Noriega, R. F., Cárdenas, J. R. “The Mounting Hezbollah Threat in Latin America.” American Enterprise Institute for Public Policy Research October 2011, no 1.

Organized Crime Networks Targeted in INTERPOL - Coordinated Operation in TriBorder area, Web 2 March 2019 https://www.interpol.int/News-and-media/ News/2016/N2016-047.

Ortiz, R. D. “El terrorismo yihadista en América Latina: ¿La amenaza ignorada?” Terrorismo sin fronteras. Actores, escenarios y respuestas en un mundo global. Eds. J. Jordán, P. Pozo, M. G. Guindo, Pamplona: Aranzadi, 2010.

Rocha, M., Zorovich, S. “The Power of Organized Crime in Brazil: From Public and Social Challenges to the Effectiveness of Reforms." Drug Trafficking, Organized 
Crime, and Violence in the Americas Today. Eds. B. B. Bagley, J. D. Rosen, Gainesville: University Press of Florida, 2015.

Sageman, M. Leaderless Jihad. Terror Networks in the Twenty-First Century, Philadelphia: University of Pennsylvania Press, 2008.

Seguridad Ciudadana en América Latina. Miradas críticas a procesos institucionales.

Eds. H. Frühling Ehrlich, Santiago de Chile: Romina Nespolo, 2011.

Śniadecka-Kotarska, M. "Walka z narkohandlem a stosunki polityczne Peru - Stany Zjednoczone." Ameryka Łacińska 2 (2006): 32-44.

Terrorismo sin fronteras. Actores, escenarios y respuestas en un mundo global. Eds.

J. Jordán, P. Pozo, M. G. Guindo, Pamplona: Aranzadi, 2010.

Umaña, F. Revisiting the Crime-Terrorism Nexus in the Tri-Border Area, The Fund for Peace, 2012.

Stanisław Kosmynka - Ph.D., Professor at the University of Lodz, Faculty of International and Political Studies, Department of Latin American and Comparative Studies. Author of two monographs: Od Boga do terroru. Rola religii $w$ ideologii dżihadyzmu na przykładzie organizacji Al-Kaida [From God to Terror: Role of Religion in Jihad Ideology-Formation on the Example of Al.-Quaida, 2012], Swięta wojna w Al-Ándalus. Przeobrażenia aktywności dżihadystycznych komórek terrorystycznych w Hiszpanii w latach 1995-2012 [Holy War in Al-Ándalus: Transforming Jihad Terrorist Cells in Spain, 1995-2012; 2015] and numerous articles. His main research areas focus on the manifestations of the jihadist terrorism in Spain as well as on political leadership in Latin America. He analyses the relations between the politics and religion, challenges for the security in the Mediterranean region and in South America. In 2009-2014 he was a visiting professor in Spain in the Universities of Granada, Santiago de Compostela, La Laguna and Vic. 